\title{
The permittistat: a novel type of turbidostat
}

\author{
Gerard H. Markx, Christopher L. Davey and Douglas B. Kell* \\ Department of Biological Sciences, University College of Wales, Aberystwyth, Dyfed SY23 3DA, UK
}

(Received 21 August 1990; revised 22 November 1990; accepted 7 January 1991)

\begin{abstract}
Baker's yeast was grown in a novel type of turbidostat in which the steady-state biomass level was controlled not by the optical turbidity but by the dielectric permittivity of the suspension at appropriate radio frequencies. Dry weight, fresh weight, the optical density at $600 \mathrm{~nm}$, percentage viability (from methylene blue staining), bud count and ethanol concentration were measured off-line and the cell size distribution was recorded using flow cytometry. Any changes in the physiological properties of the yeast had a negligible effect on the ratio between the permittivity set (and measured) and the steady-state dry weight, fresh weight or optical density of the cultures. The permittistat was found to provide an extremely convenient means for carrying out turbidostatic culture.
\end{abstract}

\section{Introduction}

Amongst the possible forms of continuous culture (Tempest, 1970; Pirt 1975), it is usual to distinguish those (such as the chemostat) in which the dilution rate is fixed by the experimenter and growth is nutrient-limited, and those, such as the turbidostat (Bryson \& Szybalski, 1952) or pHauxostat (Martin \& Hempfling, 1976) in which cell growth is not nutrient-limited and in which the inflow of fresh nutrients is controlled via a feedback loop responding to some growth-associated parameter. Although the chemostatic and turbidostatic modes of growth are fundamentally similar (Herbert, 1958), the volumetric productivity of biomass displayed by turbidostats is the greatest achievable for a given organism and environment, and, from a control engineering point of view, the system is stable at high dilution rates, corresponding to values approaching $\mu_{\max }$.

In a turbidostat the biomass level in the fermenter is determined continuously, the nutrient pump being turned on when it exceeds a set point. The usual method of biomass estimation is via the optical turbidity of the cell suspension (Myers \& Clark, 1944; Bryson \& Szybalski, 1952; Anderson, 1953, 1956; Northrop, 1954; Moss, 1956; Cooper et al., 1959; Schlecht et al., 1958; Herbert et al., 1965; Dean, 1967; Moss \& Bush, 1967; Blachere \& Jamart, 1969; Munson, 1970; Edwards et al., 1972; Agrawal, 1987). However, turbidity measurements have two major drawbacks: (i) they are only linear (in

\footnotetext{
* Author for correspondence. email: DBK@UK.AC. ABERYSTWYTH.
}

terms of the Beer-Lambert law) over a limited range of values of biomass, and become useless at optical densities exceeding approximately 4 (corresponding for a $1 \mathrm{~cm}$ path length to approximately $2 \mathrm{mg}$ dry $\mathrm{wt} \mathrm{ml}^{-1}$ ), and (ii) the optical sensors used in turbidity measurements are extremely prone to fouling by the microorganisms which they are attempting to measure. In addition, non-cellular particulate material in suspension will contribute to the signal.

An important, and now perhaps more popular, alternative to the optical turbidostat is the pHauxostat (Martin \& Hempfling, 1976; Stouthamer \& Bettenhaussen, 1976; Oltmann et al., 1978; MacBean et al., 1979; Bungay et al., 1981; Rice \& Hempfling, 1985; Minkevich et al., 1989; Fraleigh et al., 1989, 1990; von Schulthess et al., 1990), in which the growth-associated microbial production of acid (or, in principle, base) causes a change in $\mathrm{pH}$ which is returned to its set-point not by the addition of alkali per se but by the addition of a more alkaline nutrient medium; the biomass level in the steady state is then determined by the buffering power of the medium (whilst the dilution rate again corresponds to a value approaching $\mu_{\max }$ for the medium and conditions employed). The pHauxostat is relatively straightforward to implement, but has the disadvantages that (i) the biomass level is still set indirectly, (ii) there is a limit to the range of buffering powers which can be provided, and (iii) the cells must actually change the external $\mathrm{pH}$ by a substantial amount as a result of their catabolic activities [which is not always the case (Watson, 1972; Firstenberg-Eden \& Eden, 1984)]. Other indirect methods for the estimation of biomass include the electrical 
conductance of the medium (Firstenberg-Eden \& Eden, 1984; Ebina et al., 1989, Ryu et al., 1990) and the rate of $\mathrm{CO}_{2}$ production (Watson 1969, 1972). Overall, however, because of these difficulties, and especially the problems with the optical methods, the generalized turbidostatic mode of growth has been, and remains, little-exploited.

Nowadays, there is much interest in (and progress towards) the direct and on-line determination of biomass levels, especially using physical approaches which (alone) permit the registration of biomass in real time (Harris \& Kell, 1985a, Clarke et al., 1986; Kell et al., 1990). Thus, turbidostats can be imagined in which biomass levels are determined directly using methods other than the optical turbidity of a culture, for use as the feedback signal to the nutrient pump.

Dielectric spectroscopy at radio frequencies has already proven to be a useful tool for the estimation of the biomass levels of many different kinds of organisms (Harris et al., 1987; Davey et al., 1988, 1991; Boulton et al., 1989; Kell \& Todd, 1989; Stoicheva et al., 1989; Ferris et al., 1990; Kell et al., 1990; Markx \& Kell, 1990; Peñaloza et al., 1991; Salter et al., 1990). The method gives a signal that is linear with the volume fraction of biomass that is present in a cell suspension up to very high biomass levels (Harris \& Kell, 1983). Since adherence of material to the sensor (fouling) can be prevented by the application of electrolytic cleaning pulses to the electrodes (Dhar, 1986; Markx \& Kell, 1990), and non-cellular material is not detected, it could prove a useful alternative method for the control of biomass levels in fermenters.

The purpose of the present article is therefore to describe our implementation of this type of turbidostat based on the measurement of dielectric permittivity. Since the control of the biomass level in such a system is not based on the turbidity of the suspension the name turbidostat is not really applicable; we therefore propose the name 'permittistat' for a fermentation system in which the biomass is kept at a constant level by a feedback mechanism based on the dielectric permittivity of the suspension.

\section{Theory}

The relevant aspects of the theory of dielectric spectroscopy have been described in many publications (Grant et al., 1978; Schanne \& Ceretti, 1978; Pethig, 1979; Zimmermann, 1982; Kell \& Harris, 1985 b; Foster \& Schwan, 1986, 1989; Kell, 1987, 1988; Pethig \& Kell, 1987; Davey \& Kell, 1989, 1990; Takashima, 1989; Kell \& Davey, 1990). Here it will suffice to say that the linear, passive electrical properties of biological (and other) materials can be completely described by their capacitance and conductance. Capacitance gives a measure of the ability of the material to store electric field energy (as charge), whilst conductance gives a measure of the ability to conduct charge and thus dissipate electric field energy as heat. The capacitance and conductance are macroscopic, extensive variables (reflecting the intrinsic properties permittivity and conductivity), whose magnitude depend upon the area $A$ of the (plane-parallel) electrodes used and the distance $d$ between them. Thus we have

$$
\begin{aligned}
& \varepsilon=C\left(d / A \varepsilon_{0}\right) \\
& \sigma=G(d / A)
\end{aligned}
$$

where (with their SI units in parentheses), $\varepsilon=$ permittivity $(-)$, $\varepsilon_{0}=$ permittivity of free space $\left(8.854 \times 10^{-12} \mathrm{~F} \mathrm{~m}^{-1}\right), C=$ capacitance (F), $\sigma=$ conductivity $\left(\mathrm{S} \mathrm{m}^{-1}\right), G=$ conductance $(\mathrm{S})$ and $d / A=$ cell constant $\left(\mathrm{m}^{-1}\right)$.

The dielectric properties of (intact) biological cells are strongly frequency-dependent. In the radio-frequency range, the permittivity falls and the conductivity rises with increasing frequency, between two plateau values. This is because at the lower frequencies electrical charges are unable to cross the molecularly thin cell membrane insulating the electrically conductive cytoplasm from the electrically conductive extracellular medium, so that a large macroscopic capacitance is observed. Since the current is shunted only via the extracellular phase, the conductivity is low, reflecting only that of the extracellular medium (Harris \& Kell, 1983; Lovitt et al., 1983). At the higher frequencies, the electrical field can short-circuit the membrane capacitance, the macroscopic capacitance falls, and the conductance rises (due to the fact that the intracellular conductivity is now contributing to it). This phenomenon is known as the $\beta$-dispersion (Schwan, 1957). The size of the permittivity change $\Delta \varepsilon\left(=\varepsilon_{1}-\varepsilon_{\mathrm{h}}\right)$ due to the $\beta$-dispersion is given (Schwan, 1957), for spherical cells up to a volume fraction of approximately $0 \cdot 3$, by

$$
\varepsilon_{1}=\varepsilon_{\mathrm{h}}+9 \operatorname{Pr} C_{\mathrm{m}} / 4 \varepsilon_{0}
$$

where $\varepsilon_{1}=$ 'low-frequency' permittivity $(-), \varepsilon_{\mathrm{h}}=$ "high-frequency" permittivity $(-), P=$ volume fraction of biomass, i.e. the total (intra)cellular volume/the total culture volume $(-), r=$ equivalent radius of cell $(\mathrm{m})$ and $C_{\mathrm{m}}=$ membrane capacitance $\left(\mathrm{F} \mathrm{m}^{-2}\right)$.

The value of $\Delta \varepsilon$ or the 'dielectric increment' of a cell suspension is therefore dependent on the volume fraction of biomass, the cell size and the membrane capacitance per unit area (typically $0.5-1 \mu \mathrm{F} \mathrm{cm}^{-2}$ ). The characteristic frequency $f_{\mathrm{c}}$ of a dispersion is the frequency at which it is half-completed, i.e. that at which $\varepsilon=\varepsilon_{\mathrm{h}}+\Delta \varepsilon / 2=\varepsilon_{\mathrm{h}}+\left(\varepsilon_{1}-\varepsilon_{\mathrm{h}}\right) / 2$ and is related to the relaxation time $\tau$ by $\tau=\left(2 \pi f_{\mathrm{c}}\right)^{-1}$. That of the $\beta$-dispersion depends upon the cell radius, $C_{\mathrm{m}}$, and the conductivities internal $\left(\sigma_{\mathrm{i}}\right)$ and external $\left(\sigma_{\mathrm{o}}\right)$ to the cells, according to the relation $\tau=r C_{\mathrm{m}}\left[1 / \sigma_{\mathrm{i}}+1 /\left(2 \sigma_{\mathrm{o}}\right)\right]$. Thus the conductivity of a suspension can also affect the permittivity measured at a particular frequency (Harris et al., 1987), but the effect can be minimized by the choice of appropriate frequencies (on the plateaus of the dispersion).

In biological work, it is also common to characterize dielectric dispersions in terms of the Cole-Cole $\alpha$ (Cole \& Cole, 1941), which is an empirical parameter used to describe the breadth of a relaxation and which is generally thought to reflect the distribution of relaxation times of a dispersion (see e.g. Pethig \& Kell, 1987).

The above description represents the 'classical' explanation of the origins of the $\beta$-dispersion, and these factors certainly dominate its cause. However, it is fair to point out that the classical explanation alone is not consistent with the effects of cross-linking reagents (Harris $\&$ Kell, 1985b, Symons et al., 1986), the excessively great values of the Cole-Cole $\alpha$ (Kell \& Harris, 1985a, $b$; Pethig \& Kell, 1987) and the temperature-dependence of the dielectric increments observed (Ferris et al., 1990), such that other effects, in particular the lateral diffusion and activity of membranous proteins (Harris \& Kell, 1985b, Kell \& Harris, 1985b), must also contribute to the $\beta$-dispersion in biological cell suspensions. 


\section{Methods}

Organism. The yeast used was baker's yeast obtained locally. The yeast was plated out and a clone taken from one colony was propagated and used as the inoculum. The yeast was grown on a medium containing the following (all w/v): sucrose, $5 \%$; yeast extract (Lab M), $0.5 \%$, bacterial peptone (Lab M), $0.5 \%$. The $\mathrm{pH}$ was set at 5.0 with phosphoric acid before autoclaving the medium

Fermentation system. For permittistatic culture, the cells were grown anaerobically. The fermenter vessel (LH Engineering) had a volume of 1 litre and the temperature of growth was $27^{\circ} \mathrm{C}$. The top of the fermenter was adapted to allow the insertion of the probe of the dielectric spectrometer. 'Oxygen-free' (white spot) nitrogen gas was sparged through the medium. The fermenter was stirred at 500 r.p.m. using a $4 \mathrm{~cm}$ diameter Rushton-type impeller. The $\mathrm{pH}$ was controlled at 5.0 with a $\mathrm{pH}$ stat, using $1 \mathrm{M}-\mathrm{KOH}$. The working volume was controlled at $470 \mathrm{ml}$ by pumping medium out continuously through an overflow. Medium was pumped in using a Watson-Marlow peristaltic pump. The capacitance at 'low' and 'high' frequencies, the high-frequency conductance and the state (on/off) of the nutrient pump at the inflow were monitored continuously using a Blackstar 2308 interface (analogto-digital converter) and an Opus II IBM-compatible PC. The same computer/interface system was used to control the measurement frequency and the biomass level. The difference between the capacitance at low and high frequencies was used to switch the pump at the inflow on or off in order to control the biomass level in the fermenter. A hysteresis of $0.2 \mathrm{pF}$ was allowed for the first three setpoints of Fig. 1, and of $0.1 \mathrm{pF}$ during the rest of the experiments: $0.1 \mathrm{pF}$ corresponds, for the stated cell constant, to a permittivity difference of some 0.9 permittivity units. Every $66 \mathrm{~min}$ during the batch phase of the permittistat culture a full frequency scan of the capacitance (and conductance) was performed automatically. Samples for off-line analysis were taken aseptically three times a day during continuous cultures.

Off-line measurements. Fresh weights were measured by filtering $5 \mathrm{ml}$ of suspension over $25 \mathrm{~mm} 0.2 \mu \mathrm{m}$ cellulose nitrate Whatman filters. Dry weights were measured by drying the above filters plus cells in a drying oven $\left(105^{\circ} \mathrm{C}\right)$ overnight.

Optical densities were measured at $600 \mathrm{~nm}$ using a cell with a path length of $1 \mathrm{~cm}$ in a CamSpec spectrophotometer; samples with values of optical density greater than 0.5 were diluted.

Methylene blue staining, a well-known measure of yeast cell viability (Jones, 1987; Boulton et al., 1989) was performed as described previously (Stoicheva et al., 1989).

Bud counts were performed microscopically. Only cells that clearly consisted of connected cells were counted as budding cells. During the stationary phase of the batch culture aberrant morphologies were found; they were not counted as budding cells.

Ethanol concentrations were measured using procedure 332-UV from Sigma, which is based on the enzyme oxidation of alcohol by $\mathrm{NAD}^{+}$in the presence of alcohol dehydrogenase.

A concentrated invertase solution $(5 \mu \mathrm{l})$ was added to $1 \mathrm{ml}$ of the medium to convert sucrose to fructose and glucose. After a period of $30 \mathrm{~min}$ glucose was measured using the colorometric, enzymic procedure 115 from Sigma

Flow cytometry. For the flow cytometry $1 \mathrm{ml}$ samples containing $1 \%$ $(\mathrm{w} / \mathrm{v})$ glutaraldehyde were stored in the cold room. The flow cytometer used was a Skatron Argus 100 (Skatron, Newmarket, UK), whose optics (Steen, 1990) and the means by which linearization of the calibration curve was achieved have been described elsewhere (Davey et al., 1990a). This instrument can measure both the fluorescence and elastic light scattering of particles. In the present experiments we used only low-angle light scattering, which gives a measure of particle size (e.g. Sharpless et al., 1977; Salzman et al., 1979; Latimer, 1982; Salzman, 1982; Kerker, 1983; Koch, 1984, 1986; Harding, 1986). The machine was used with the photomultiplier tube set at $390 \mathrm{~V}$ and a linear gain of 4. Calibration was done using 3,5,7 and $10 \mu \mathrm{m}$ diameter latex calibration beads, and cell sizes are given as the diameter of the equivalent sphere, based on the calibrating latex beads.

Dielectric measurements. The dielectric measurements were performed using a four-terminal dielectric spectrometer designed for the registration of microbial biomass, a Bugmeter ${ }^{\mathrm{TM}}$, produced by Aber Instruments, Aberystwyth, UK. This instrument uses a probe consisting of four gold pins embedded in an autoclavable plastic, and fits a standard $25 \mathrm{~mm}$ Ingold-type port. The cell constant of this probe was $0.80(3) \mathrm{cm}^{-1}$, and was determined using $\mathrm{KCl}$ solutions of known specific conductivity. The Bugmeter was controlled as described above, using an Opus II IBM-XT compatible PC and a Blackstar 2308 interface (ADC). To compensate for drift and fluctuations in the signal caused by external influences such as changes in the ambient temperature, the (im)perfection of electrical grounding and so on, the measurements were performed by comparison of the signal at a low frequency $(0.4 \mathrm{MHz})$ with that at a high frequency $(9.5 \mathrm{MHz})$. We refer to this measurement as the delta permittivity value. Since instrumental drift and fluctuations have the same effect on signals at low and high frequencies, and only the signal at low frequencies contains a component related to the biomass present, this method allows one to compensate for such artefacts. The method has already been exploited successfully in the measurement of the dielectric properties of biofilms (Markx \& Kell, 1990).

The Bugmeter also contains a unit which allows one to generate gas bubbles on the electrode surface by electrolysis of the medium, in order to clean the electrode. This option was not used in the present work since biofilm formation was found to be minimal.

\section{Results}

We first determined the relationship between the difference in permittivity at $0.4 \mathrm{MHz}$ and that at

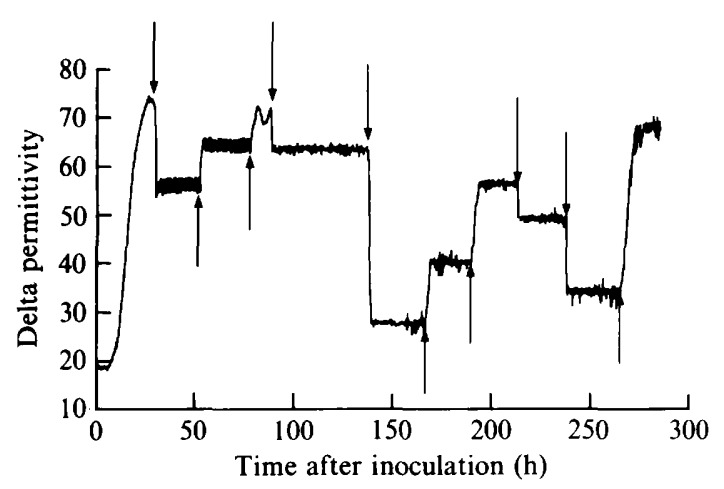

Fig. 1. Changes in the permittivity at $0.4 \mathrm{MHz}$ relative to that at 9.5 $\mathrm{MHz}$ during the continuous culture of baker's yeast at different setpoints. A permittistat was set up as described in Methods. Cells were initially grown in batch culture mode. At the first arrow (about $28 \mathrm{~h}$ after inoculation), the permittistatic mode of operation was initiated. The setpoint (for the difference in permittivity at $0.4 \mathrm{MHz}$ minus that at $9.5 \mathrm{MHz}$ ) was subsequently changed at the points (marked by arrows) where the delta permittivity measured exhibits a step. 

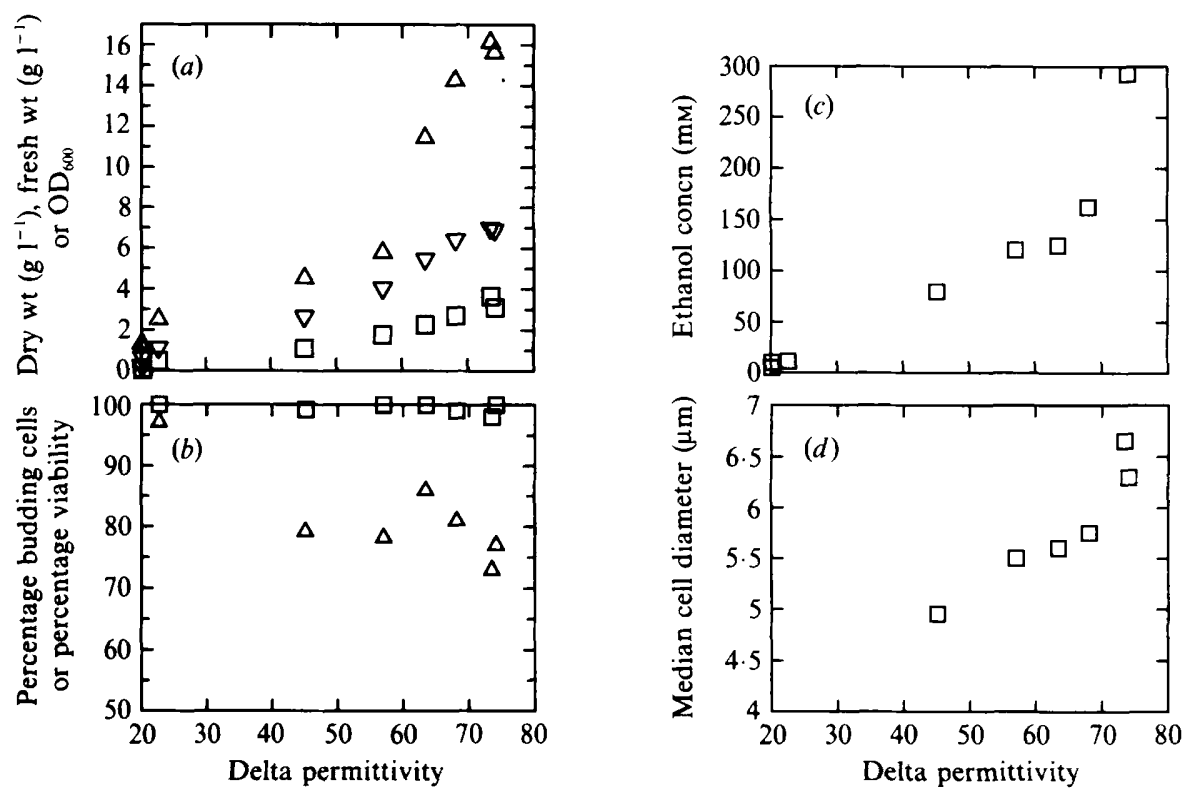

Fig. 2. Changes in $(a)$ the dry weight $(\square)$, fresh weight $(\triangle)$ and $\mathrm{OD}_{600}(\nabla),(b)$ the percentage viability (staining with methylene blue) $(\square)$ and bud count $(\triangle),(c)$ the ethanol concentration and $(d)$ the median cell size, as a function of the difference in permittivity between 0.4 and $9.5 \mathrm{MHz}$ during batch culture of baker's yeast. Measurements were taken from the run displayed in Fig. 3.

$9 \cdot 5 \mathrm{MHz}$, as a function of the dry weight, for cell suspensions taken from a yeast culture. The data showed that the permittivity was linear with the biomass present to values of biomass concentration greatly in excess of those used in the present work (data not shown, but see also Stoicheva et al., 1989).

The changes in the permittivity difference between $0 \cdot 4$ and $9.5 \mathrm{MHz}$ during a continuous fermentation of baker's yeast are given in Fig. 1. It may be noted that the $\mu_{\max }$ of this organism in the stated medium under conditions of batch growth was $0.52 \mathrm{~h}^{-1}$. Once the stationary phase was achieved after the initial batch growth (at about $25 \mathrm{~h}$ ) the biomass was controlled at different permittivity levels. At the third arrow too high a setpoint for the amount of nutrients in the feed was chosen, and the control of the biomass level was momentarily stopped. Overall, however, it may be seen that the permittistat provided an excellent degree of control of the biomass set, and that excursions in the biomass level were within the hysteresis built in to the control loop.

Fig. 2(a) shows the changes in the dry weight, fresh weight and optical density during the batch culture phase of the permittistat following inoculation. Also shown are the changes in the viability and bud count (Fig. $2 b$ ), the ethanol content of the medium (Fig. $2 c$ ) and the median cell size during the batch culture (Fig. $2 d$ ). The fact that the plots in Fig. 2(a) do not extrapolate to values of zero permittivity units on the abscissa is due to an instrumental artefact (non-flat baseline) in the particular instru-

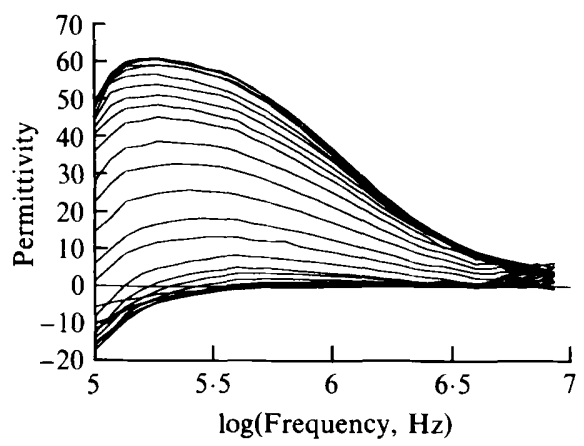

Fig. 3. Frequency dependence of the permittivity of baker's yeast during growth in batch culture. Measurements were performed as described in Methods and in the legend to Fig. 1, during the batch phase of growth. The decreases in permittivity at the low-frequency end are an instrumental artefact, as may be observed in the lowest curve which represents the medium shortly after inoculation.

ment used. From these data (Fig. 2) it may be inferred that the relevant parameters for this strain in batch culture are delta capacitance (and in square brackets delta permittivity) equal to $1.93 \mathrm{pF}[17.5$ permittivity units] (mg dry wt) $)^{-1} \mathrm{ml}^{-1}, 0.43 \mathrm{pF}[3.9$ permittivity units] (mg wet wt) ${ }^{-1} \mathrm{ml}^{-1}$ and $0.93 \mathrm{pF}$ [8.5 permittivity units] $\left(\mathrm{OD}_{600} \text { unit }\right)^{-1}$, the percentage viability is approximately $100 \%$ and the percentage of budding cells equals 70 $100 \%$. It may also be observed that the median cell size (for definition and means of measurement see Davey $e t$ $a l ., 1990 b$ ) increases slightly and monotonically as a function of the permittivity. This behaviour may be 

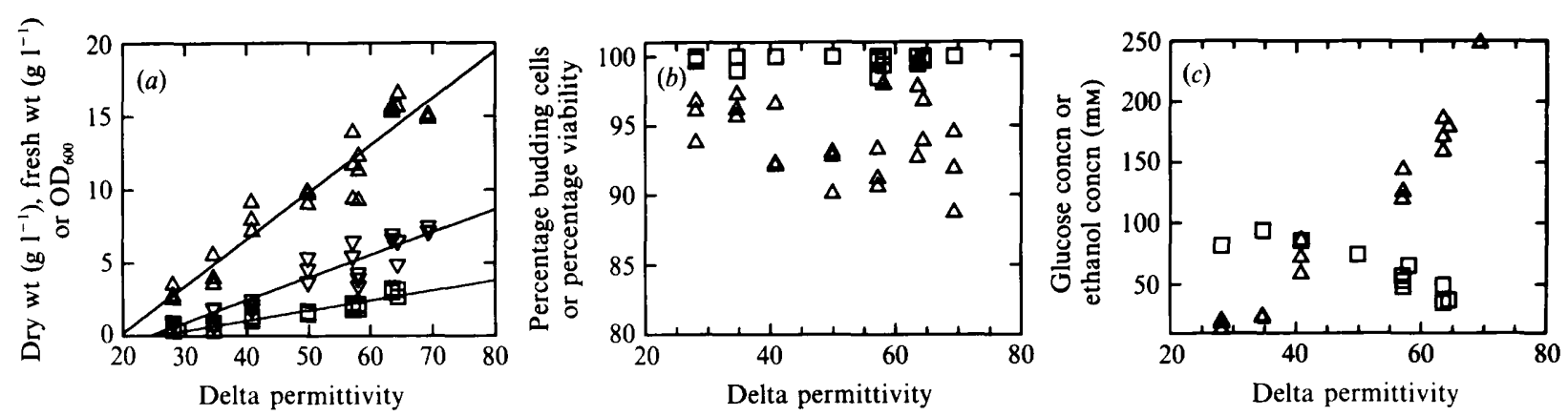

Fig. 4. Changes in $(a)$ the dry weight $(\square)$, fresh weight $(\triangle)$ and $\mathrm{OD}_{600}(\nabla),(b)$ the percentage viability (staining with methylene blue) $(\square)$ and bud count $(\triangle)$ and $(c)$ glucose $(\square)$ and ethanol $(\triangle)$ concentrations as a function of the difference in permittivity between 0.4 and $9.5 \mathrm{MHz}$ during permittistat culture of baker's yeast. Measurements were taken both from the run displayed in Fig. 1 and from similar experiments. In (a), the lines represent the best fits to the data according to a linear least-squares fit (Leatherbarrow, 1990).

ascribed to the well-known observation that, if growing, faster-growing cells are larger [see also Alberghina et al. (1983) and Ranzi et al. (1986), who studied aerobically grown yeast], and throughout the batch culture the cells are constantly accelerating out of the lag phase.

In Fig. 3 are shown the changes in the frequency scans during the batch phase of the culture. From these, using the spreadsheet program for fitting dielectric data that we have described previously (Davey et al., 1990c), it may be inferred that the characteristic frequency of the $\beta$-dispersion under these conditions (i.e. the frequency at which it is half-completed) remains fairly constant at some $1.2 \mathrm{MHz}$ ( $\log$ frequency $=6.08$ in Fig. 2). From these data, it is also possible to determine the value of the Cole-Cole $\alpha$, a method of potential use for the rapid characterization of morphological changes in microbial cultures in that elongated or otherwise non-spherical cells would be expected to display a greater distribution of relaxation times. We observed (data not displayed) that the Cole-Cole $\alpha$ decreased rather smoothly from a value of 0.13 upon inoculation to 0.06 as cells began to enter the stationary phase.

A number of cultures were studied in the manner displayed in Fig. 1, with different values of the biomass setpoint. Fig. 4(a) displays the dry weight, fresh weight and optical density as a function of the setpoint used, whilst Fig. 4(b) and Fig. 4(c) show, respectively, the changes in the percentage viability and the bud counts and the steady-state glucose and ethanol concentrations. From these data it may be inferred that in permittistat culture this strain has a delta capacitance (delta permittivity in square brackets) equal to $1.64 \mathrm{pF}[14.9$ permittivity units] (mg dry $\mathrm{wt})^{-1} \mathrm{ml}^{-1}, 0 \cdot 36 \mathrm{pF}[3 \cdot 2$ permittivity units] (mg fresh $\mathrm{wt})^{-1}$ and $0.71 \mathrm{pF}$ [6.4 permittivity units] $\left(\mathrm{OD}_{600} \text { unit }\right)^{-1}$. It is also of interest to note the generally good linearity between the steady-state ethanol concentration and the permittistat setpoint, consistent with the view that any setpoint-dependent

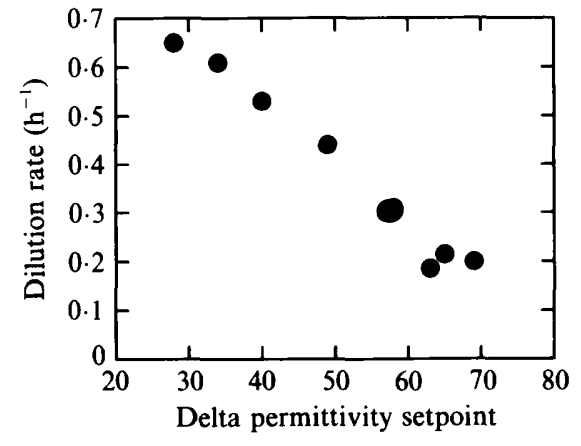

Fig. 5. Effect of the permittistat setpoint on the dilution rate. Measurements were taken from the run displayed in Fig. 1.

changes in the cellular physiology or primary metabolism were insignificant over the range of setpoints studied.

In Fig. 5 the changes in the dilution rate during the experiment are plotted versus the setpoint used. It may be observed that the dilution rate is a monotonically decreasing function of the setpoint, possibly suggesting that under the present conditions the organisms were not in a medium providing a very large excess of nutrients (Munson, 1970). From the measurements of glucose and ethanol concentrations (Fig. $4 c$ ) it may be inferred that the cells probably did not become glucose-limited, even at the highest permittivity setpoint used. Although we did not study this point in detail, such data could perhaps best be accounted for if the cells were subject to increasing levels of ethanol toxicity (see e.g. Brown \& Oliver, 1982; Ingram \& Buttke, 1985; Jones \& Greenfield, 1986; van Uden, 1989) or other product inhibition as the permittivity setpoint was raised, since the steadystate ethanol concentrations (Fig. 4c) were quite large, and in inverse ratio to the steady-state biomasses.

The extent of low-angle light-scattering from bacteria and similar objects depends on their biomass, but the amount of light scattered per unit biomass is relatively 


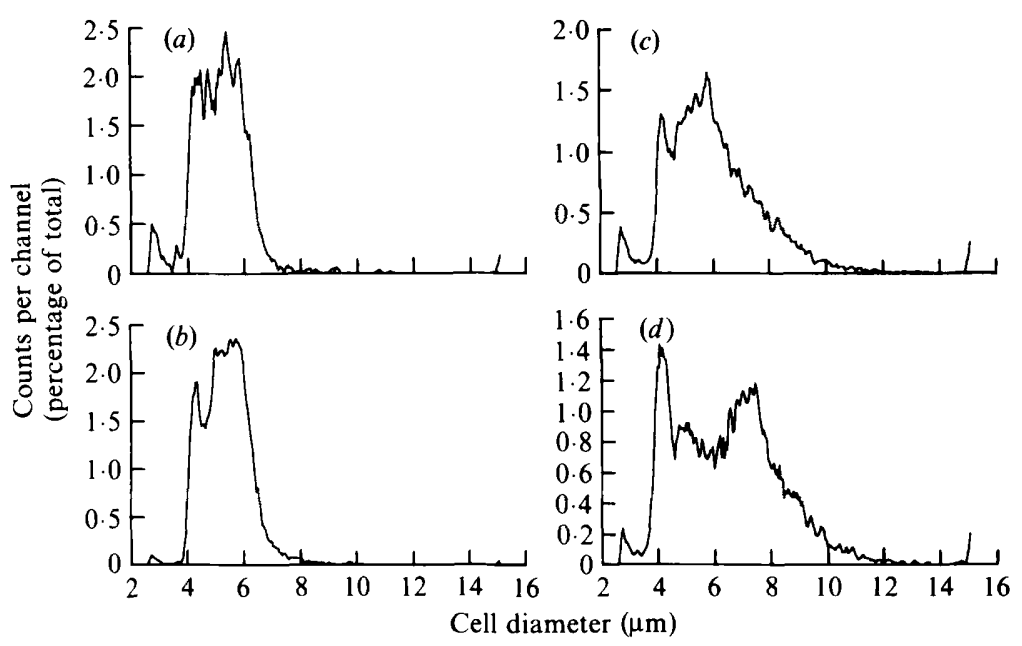

Fig. 6. Typical cell size distributions during the permittistat culture of baker's yeast. (a) Low (3.82 pF, 34.6 permittivity units), (b) middle (6.3 pF, 57.1 permittivity units), (c) high ( $7 \mathrm{pF}, 63.5$ permittivity units) and $(d)$ very high $(7.64 \mathrm{pF}, 69.3$ permittivity units) setpoint. Measurements were performed using the flow cytometric apparatus as described in Methods. independent of the cell size (e.g. Wyatt, 1968; Sharpless et al., 1977; Salzman et al., 1979; Latimer, 1982; Salzman, 1982; Kerker, 1983; Koch, 1984, 1986; Harding, 1986; Carr et al., 1987). This type of behaviour contrasts with that relating permittivity per unit biomass and cell size, where the former is proportional to, rather than independent of, the latter (see Theory section). Thus it was of interest to examine how the distribution of cell sizes (recorded by light-scattering) varied as a function of the biomass concentration set by the permittistat.

Fig. 6 displays typical cell size distributions at low $(6 a)$, middle $(6 b)$, high $(6 c)$ and very high $(6 d)$ setpoints. At low setpoints, two peaks are seen, one around $4.3 \mu \mathrm{m}$ and one around $6 \mu \mathrm{m}$. With increasing setpoint the peak of the larger cells shifts to greater cell sizes, thus making the small peak more apparent. The cell size distribution also becomes more broad with increasing setpoint. Such data would be consistent with the view that the increasing steady-state concentrations of ethanol as the permittistat setpoint was raised were more toxic towards

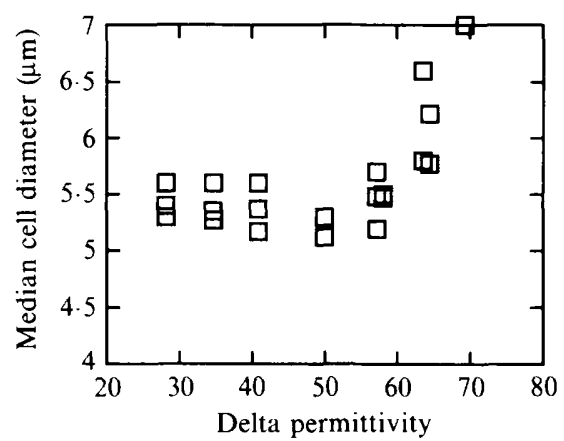

Fig. 7. Effect of permittistat setpoint on the median cell diameter. The experiments were performed exactly as described in the legend to Fig. 6 , and made use of the computer programs described by Davey et al. $(1990 a, b)$. division than towards biomass accretion per se. From these and other data, we also determined the median cell size as a function of the permittivity setpoint. It may be observed, however (Fig. 7), that the median cell size is more-or-less independent of the setpoint except at the highest setpoints (and lowest dilution rates) used.

\section{Discussion and Conclusions}

In the present article, we have described the design and implementation of a novel type of turbidostat, the permittistat, in which cell density is continuously recorded (and controlled) not optically but dielectrically. We found (Fig. 1) that the system could accurately maintain biomass concentration to within the hysteresis level built into the control loop, viz. $0.1 \mathrm{pF}$, correspond-

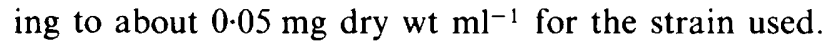

In a 'true' turbidostat, it is desirable that the parameter actually controlled, e.g. optical turbidity, buffering power or dielectric permittivity, is linear with the 'true' biomass present, measured for instance as dry weight (since in a turbidostat the viability is usually very close to $100 \%$ ). Using cell suspensions, we showed that the dielectric method gives a signal that is indeed strictly linear with the biomass concentration to values far greater than those generally studied. However, changes in the physiology of the cells at different setpoints (corresponding to different dilution rates) might in principle be expected to affect the slope of the line relating permittivity to biomass.

In batch culture, changes in the physiological properties of Saccharomyces cerevisiae only affect the specific permittivity measurements when cells enter the stationary phase (Kell et al., 1990); changes in the ratio of fresh weight, dry weight or optical density to the capacitance 
measured are normally minimal. In the permittistat cultures, these ratios were again constant within the experimental precision (Fig. $4 a$ ).

In the permittistat, the percentage of budding cells was always very high, consistent with the high viabilities observed. The reason for the lower extent of budding of the cells in the batch phase of the permittistat culture (Fig. 2) is unknown, but is plausibly related to their emergence from the lag phase. However, viability changes are minimal during the experiments with the permittistat itself.

Interestingly, the dilution rate attained in these permittistats was a moderately sharp function of the permittivity setpoint. Although at the highest values of the latter, the cells conceivably became at least partially nutrient-limited, this behaviour is more simply ascribed to the toxic effects of the ethanol (or other product) produced by the anaerobically growing cells, since the strain used (a commercial baker's yeast) would have been grown and selected aerobically, conditions under which ethanol resistance would not have been selected. Indeed, a simple but ingenious modification to a turbidostat permits the selection of strains more tolerant to ethanol (Brown \& Oliver, 1982).

The only substantial changes in cell physiology that we detected were an increase in median cell size at the highest setpoints (lowest dilution rates) used. Here, a change in the cell composition is arguably to be expected, since accumulation of reserve material is a common phenomenon in yeast (e.g. Trivedi \& Jacobson, 1986; Quain, 1988). No iodine-stainable material was detected during the experiment (data not shown), but it is of course possible that material (such as trehalose) that could not be stained by iodine was accumulated. Notwithstanding, the important consideration is that the dry and fresh weights of the culture remained linear with the parameter actually controlled, viz. the permittivity difference.

Turbidostats (and chemostats) are often used in experiments investigating adaptations of organisms to their environment, including the rate of appearance and selection of mutations (e.g. Northrop \& Kunitz, 1957; Bryson, 1958; Munson \& Bridges, 1964; Munson, 1970; Kubitschek, 1974; Harder et al., 1977, James, 1978; Brown \& Oliver, 1982; Dykhuizen \& Hartl, 1983; Fraleigh et al., 1989). Turbidostats and chemostats put selection pressures on the organism that is under study, thus selecting for those best adapted to the (artificial) environment. The use of alternative sensors for biomass level determination would set selection criteria different from those set by methods using optical turbidity measurements. Particularly since the control signal generated by the permittistat is cell-size-dependent (per unit biomass), one may imagine cell selection on the basis of cell size. In addition, the present instrumentation provides signals reflecting the frequency-dependent conductivity of the system; thus control signals based on internal or external conductivity could also be used. The implementation of these refinements, and the selection pressures observed, will be described elsewhere.

We thank the Science and Engineering Research Council, UK and ICI Biological Products for financial support of this work, and Aber Instruments for the use of a Bugmeter. D. B.K. thanks Dr Hans Westerhoff for many stimulating discussions concerning turbidostatic cultures and other topics.

\section{References}

Agrawal, P. (1987) An experimental study of a modified turbidostat. Biotechnology Techniques 1, 19-24.

alberghina, L., Mariani, L., Martegani, E. \& Vanoni, M. (1983). Analysis of protein distribution in budding yeast. Biotechnology and Bioengineering 25, 1295-1310.

ANDERSON, P. A. (1953). Automatic recording of the growth rates of continuously cultured microorganisms. Journal of General Physiology 36, 733-777.

ANDERSON, P. A. (1956). Continuous recording of the growth of microorganisms under turbidostatic and chemostatic control. Review of Scientific Instruments 27, 48-51.

BLACHERE, H. \& JAMART, G. (1969). A flow cell photometer for bacterial growth monitoring. Biotechnology and Bioengineering 11, 1005-1010.

Boulton, C. A, Maryan, P. S. \& Loveridge, D. (1989). The application of a novel biomass sensor to the control of yeast pitching rate. Proceedings of the 22nd European Brewing Convention, Zürich, pp. 653-661.

Brown, S. W. \& Oliver, S. G. (1982). Isolation of ethanol-tolerant mutants of yeast by continuous selection. European Journal of Applied Microbiology and Biotechnology 16, 119-122.

BRYSON, V. (1958). Application of continuous culture to microbial selection. In Recent Progress in Microbiology pp. 371-380. Edited by G. Tunevall. Oxford: Blackwell Scientific Publications.

BRYSÓN, V. \& SZYBALSKI, W. (1952). Microbial selection. Science 116, $45-51$.

Bungay, H. R., Clesceri, L. S. \& Andrianas, N. (1981). Autoselection of very rapidly growing microorganisms. In Advances in Biotechnology, vol. 1, Proceedings of the 6th International Fermentation Symposium, pp. 235-241. Edited by M. Moo-Young. Oxford: Pergamon Press.

Carr, R. J. G., Brown, R. G. W., Rarity, J. G. \& Clarke, D. J. (1987). Laser light scattering and related techniques. In Biosensors: Fundamentals and Applications, pp. 679-701. Edited by A. P. F. Turner, I. Karube \& G. S. Wilson, Oxford: Oxford University Press.

Clarke, D. J., Blake-Coleman, B. C., Carr, R. J. G., Calder, M. R. \& ATKINSON, T. (1986). Monitoring reactor biomass. Trends in Biotechnology 4, 173-178.

Cole, K. S. \& COLE, R. H. (1941). Dispersion and absorption in dielectrics. 1. Alternating current characteristics. Journal of Chemical Physics 9, 341-351.

COOPER, P. D., Wilson, J. N. \& BURT, A. M. (1959). The bulk growth of animal cells in continuous suspension culture. Journal of General Microbiology 21, 702-720.

DAVEY, C. L. \& Kell, D. B. (1989). Low-frequency dielectric properties of cell suspensions. In: Electric Field Phenomena in Biological Systems, vol. 21, IOP Short Meetings Series, pp. 51-62. Edited by R. Paris. London: Institute of Physics.

DaveY, C. L. \& Kell, D. B. (1990). The dielectric properties of cells and tissues: what can they tell us about the mechanisms of field/cell interactions? In Emerging Electromagnetic Medicine, pp. 19-43. Edited by M. O'Connor, R. H. C. Bentall \& J. S. Monahan. New York: Springer-Verlag. 
DAvey, C. L., Kell, D. B., KemP, R. B. \& Meredith, R. W. J. (1988). On the audio- and radio-frequency dielectric behaviour of anchorage-independent, mouse L929-derived LS fibroblasts. Bioelectrochemistry and Bioenergetics 20, 83-98.

Davey, C. L., Dixon, N. M. \& Kell, D. B. $(1990 a)$. FlowtovP: a spreadsheet method for linearising flow cytometric light-scattering data used in cell sizing. Binary 2, 119-125.

Davey, C. L., Kell, D. B. \& Dixon, N. M. (1990b). SKatfit: a program for determining the mode of growth of individual microbial cells from flow cytometric data. Binary 2, 127-132.

Davey, C. L., Markx, G. H. \& Kell, D. B. (1990c). Substitution and spreadsheet methods for analysing dielectric spectra of biological systems. European Biophysics Journal 18, 255-265.

Davey, C. L., Peñaloza, W., Kell, D. B. \& Hedger, J. N. (1991). Real-time monitoring of the accretion of Rhizopus oligosporus biomass during the solid-substrate tempeh fermentation. World Journal of Microbiology and Biotechnology (in the Press).

DeAN, A. C. R. (1967). Some aspects of the growth of Aerobacter aerogenes in batch culture and in the turbidostat. In Microbial Physiology and Continuous Culture, pp. 11-22. Edited by E. O. Powell, C. G. T. Evans, R. E. Strange \& D. W. Tempest, London: Her Majesty's Stationery Office.

DHAR, H. P. (1986). Electrochemical methods for the prevention of microbial fouling. In Modern Bioelectrochemistry, pp. 593-606. Edited by F. Gutmann \& H. Keyzer. New York: Plenum Press.

Dykhuizen, D. E. \& HaRTL, D. L. (1983). Selection in chemostats. Microbiology Reviews 47, 150-168.

Ebina, Y., EKIDA, M. \& Hashimoto, H. (1989). Origin of changes in electrical impedance during the growth and fermentation process of yeast in batch culture. Biotechnology and Bioengineering 33, 12901295.

Edwards, V. H., Ko, R. C. \& Balogh, S. A. (1972). Dynamics and control of continuous microbial propagators subject to substrate inhibition. Biotechnology and Bioengineering 14, 939-974.

Ferris, L. E., Davey, C. L. \& Kell, D. B. (1990). Evidence from its temperature-dependence that the $\beta$-dielectric dispersion of cell suspensions is not due solely to the charging of a static membrane capacitance. European Biophysics Journal 18, 267-276.

Firstenderg-EDEN, R. \& EDEN, G. (1984). Impedance Microbiology. Letchworth: Research Studies Press.

Foster, K. R. \& SCHWAN, H. P. (1986). Dielectric properties of tissues. In CRC Handbook of Biological Effects of Electromagnetic Fields, pp. 27-96. Edited by C. Polk \& E. Postow. Boca Raton, Florida: CRC Press.

Foster, K. R. \& SCHWAN, H. P. (1989). Dielectric properties of tissues and biological materials: a critical review. CRC Critical Reviews in Biomedical Engineering 17, 25-102.

Fraleigh, S. P., Bungay, H. R. \& Clesceri, L. (1989). Continuous culture, feedback control and auxostats. Trends in Biotechnology 7 , 159-164.

Fraleigh, S. P., Bungay, H. R. \& Clesceri, L. S. (1990). Aerobic formation of ethanol by Saccharomyces cerevisiae in a computerised pHauxostat. Journal of Biotechnology 13, 61-72.

Grant, E. H., Sheppard, R. J. \& South, G. P. (1978). Dielectric Behaviour of Biological Molecules in Solution. Oxford: Clarendon Press

HARDER, W., KuENEN, J. G. \& Matin, A. (1977). Microbial selection in continuous cultures. Journal of Applied Bacteriology 43, 1-24.

HARDING, S. H. (1986). Applications of light-scattering in microbiology. Biotechnology and Applied Biochemistry 8, 489-509.

HaRRIS, C. M. \& Kell, D. B. (1983). The radio-frequency dielectric properties of yeast cells measured with a rapid, automated, frequency-domain dielectric spectrometer. Bioelectrochemistry and Bioenergetics 11, 15-28.

HARRIS, C. M. \& KeLl, D. B. (1985a). The estimation of microbial biomass. Biosensors 1, 17-84.

HARRIS, C. M. \& KeLL, D. B. $(1985 b)$. On the dielectrically observable consequences of the movement of lipids and proteins in membranes. 2. Experiments with microbial cells, protoplasts and membrane vesicles. European Biophysics Journal 13, 11-24.

Harris, C. M., TODD, R. W., Bungard, S. J., Lovitt, R. W., MorRis, J. G. \& KELL, D. B. (1987). The dielectric permittivity of microbial suspensions at radio frequencies: a novel method for the real-time estimation of microbial biomass. Enzyme and Microbial Technology 9 , 181-186.

Herbert, D. (1958). Some principles of continuous culture. In Recent Progress in Microbiology, pp. 380-396. Edited by G. Tunevall. Oxford: Blackwell Scientific Publications.

Herbert, D., PhipPs, P. J. \& Tempest, D. W. (1965). The chemostat: design and instrumentation. Laboratory Practice 14, 1150-1161.

INGRAM, L. O. \& BuTTKe, T. M. (1985). Effects of ethanol on microorganisms. Advances in Microbial Physiology 25, 253.

JAMES, T. W. (1978). Selection and evolution of yeast cells in a chemostat. In Cell Reproduction, pp. 127-137. Edited by E. R. Dirksen, D. M. Prescott \& C. F. Fox. New York: Academic Press.

JONES, R. P. (1987). Measures of yeast deactivation and death and their meaning. Process Biochemistry 22, 118-134.

JONES, R. P. \& GREENFIELD, P. F. (1986). Role of water activity in ethanol fermentations. Biotechnology and Bioengineering 28, 29-40.

KELL, D. B. (1987). The principles and potential of electrical admittance spectroscopy : an introduction. In Biosensors : Fundamentals and Applications, pp. 427-468. Edited by A. P. F. Turner, I. Karube \& G. S. Wilson. Oxford: Oxford University Press.

KeLL, D. B. (1988). Dielectric spectroscopy of biological systems. ISI Atlas of Science: Biochemistry 1, 25-29.

KeLL, D. B. \& DAVEY, C. L. (1990). Conductimetric and impedimetric devices. In Biosensors: a Practical Approach, pp. 125-154. Edited by A. E. G. Cass. Oxford: Oxford University Press.

KeLL, D. B. \& HaRRIS, C. M. (1985a). On the dielectrically observable consequences of the movement of lipids and proteins in membranes. 1. Theory and overview. European Biophysics Journal 12, 181-197.

Kell, D. B. \& Harris, C. M. (1985b). Dielectric spectroscopy and membrane organisation. Journal of Bioelectricity 4, 317-348.

Kell, D. B. \& ToDD, R. W. (1989). Determination of biomass. United States Patent 4,810,650.

Kell, D. B., Markx, G. H., Davey, C. L. \& Todd, R. W. (1990). Realtime monitoring of cellular biomass: methods and applications. Trends in Analytical Chemistry 9, 190-194.

KeRKER, M. (1983). Elastic and inelastic light scattering in flow cytometry. Cytometry 4, 1-10

KосH, A. L. (1984). Turbidity measurements in microbiology. American Society for Microbiology News 50, 473-477.

$\mathrm{KoCH}$, A. L. (1986). Estimation of size of bacteria by low-angle lightscattering measurements: theory. Journal of Microbiological Methods $5,221-235$.

KUBITSCHEK, H. E. (1974). Operation of selection pressure on microbial populations. Symposia of the Society for General Microbiology 24, 105130.

LATIMER, P. (1982). Light scattering and absorption as methods of studying cell population parameters. Annual Review of Biophysics and Bioengineering 11, 129-150.

LEATHERBARROW, R. J. (1990) Use of nonlinear regression to analyze enzyme kinetic data: application to situations of substrate contamination and background subtraction. Analytical Biochemistry 184, 274 278

LovitT, R. W., Walter, R. P., Morris, J. G. \& Kell, D. B. (1983). Conductimetric assessment of the biomass content of immobilized (gel-entrapped) microorganisms. Applied Microbiology and Biotechnology 23, 168-173.

MacBean, R. D., Hall, R. J. \& Linklater, P. M. (1979). Analysis of $\mathrm{pH}$-stat continuous cultivation and the stability of the mixed fermentation in continuous yogurt production. Biotechnology and Bioengineering 21, 1517-1541.

MarKX, G. H. \& KeLL, D. B. (1990). Dielectric spectroscopy as a tool for the measurement of the formation of biofilms and of their removal by electrolytic cleaning pulses and biocides. Biofouling 2 , 211-227.

Martin, G. A. \& Hemprling, W. P. (1976). A method for the regulation of microbial population density during continuous culture at high growth rates. Archives of Microbiology 107, 41-47.

MinkeVich, I. G., Kryniskaya, A. YU. \& Eroshin, V. K. (1989). Bistat - a novel method of continuous cultivation. Biotechnology and Bioengineering 33, 1157-1161. 
Moss, F. (1956). Adaptation of the cytochromes of Aerobacter aerogenes in response to environmental oxygen tension. Australian Journal of Experimental Biology 34, 395-406.

Moss, F. J. \& BusH, F. (1967). Working design for a 5-liter controlled continuous culture apparatus. Biotechnology and Bioengineering 9, $585-602$.

Munson, R. J. (1970). Turbidostats. Methods in Microbiology 2, 349376.

Munson, R. J. \& BRidges, B. A. (1964). 'Take-over' - an unusual selection process in steady-state cultures of Escherichia coli. Journal of General Microbiology 37, 411-418.

Myers, J. \& ClarK, L. B. (1944). Culture conditions and the development of the photosynthetic mechanism. II. An apparatus for the continuous culture of Chlorella. Journal of General Physiology 28, 103-112.

NORTHROP, J. H. (1954). Apparatus for maintaining bacterial cultures in the steady state. Journal of General Physiology 38, 105-115.

NoRThrop, J. H. \& KUNITZ, M. (1957). The proportion of mutants in bacterial cultures. Journal of General Physiology 41, 119-129.

Oltmann, L. F., Schoenmaker, G. S., Reunders, W. N. M. \& Stouthamer, A. H. (1978). Modification of the $\mathrm{pH}$-auxostat culture method for the mass cultivation of bacteria. Biotechnology and Bioengineering 10, 921-925.

Peñaloza, W., Davey, C. L., Hedger, J. N. \& Kell, D. B. (1991). Stimulation by potassium of the growth of Rhizopus oligosporus during liquid- and solid-substrate fermentations. World Journal of Microbiology and Biotechnology (in the Press).

Pethig, R. (1979). Dielectric and Electronic Properties of Biological Materials. Chichester: John Wiley.

Pethig, R. \& Kell, D. B. (1987). The passive electrical properties of biological systems: their significance in physiology, biophysics and biotechnology. Physics in Medicine and Biology 32, 933-970.

PIRT, S. J. (1975). Principles of Microbe and Cell Cultivation. Oxford: Blackwell Scientific Publications.

QuAIN, D. E. (1988). Studies on yeast physiology - impact on fermentation performance and product quality. Journal of the Institute of Brewing 95, 315-323.

Ranzi, B. M., Compagno, C. \& Martegani, E. (1986). Analysis of protein and cell volume in glucose-limited continuous cultures of budding yeast. Biotechnology and Bioengineering 28, 185-190.

Rice, C. W. \& Hempfling, W. P. (1985). Nutrient-limited continuous culture in the pHauxostat. Biotechnology and Bioengineering 27, 187191.

RYU, D. D. Y., LEE, S. O. \& Romani, R. J. (1990). Determination of the growth rate for plant cell cultures: comparative studies. Biotechnology and Bioengineering 35, 305-311.

Salter, G. J., Kell, D. B., Ash, L. A., Adams, J. M., Brown, A. J. \& JAMES, R. (1990). Hydrodynamic deposition: a novel method of cell immobilisation. Enzyme and Microbial Technology 12, 419.430 .
Salzman, G. C. (1982). Light scattering analysis of single cells. In Cell Analysis pp. 111-143. Edited by N. Catsimpoolas. New York: Plenum Press.

Salzman, G. C., Mullaney, P. F. \& Price, B. J. (1979). Light scattering approaches to cell characterization. In Flow Cytometry and Sorting, pp. 105-124. Edited by M. R. Melamed, P. F. Mullaney \& M. L. Mendelsohn. New York: John Wiley.

SCHANNE, O. H. \& CERETTI, E. R. P. (1978). Impedance Measurements in Biological Cells. New York: John Wiley.

SCHLeCHT, S., Ring, K., KutscheR, J. \& EsChWEILER, W. (1958). Ein neuer Laboratoriumsfermenter zur Züchtung von Mikroorganismen in turbidostatischen, chemostatischen und 'batch'-Verfahren. Zeitschrift für Bakteriologie 206, 246-258.

von Schulthess, R., Bungay, H. R. \& Fraleigh, S. P. (1990). Competition in a pHauxostat. Biotechnology Letters 12, 93-98.

SchwaN, H. P. (1957). Electrical properties of tissue and cell suspensions. Advances in Biological and Medical Physics 5, 147-209.

Sharpless, T. K., Bartholdi, M. \& Melamed, M. R. (1977). Size and refractive index dependence of simple forward angle scattering measurements in a flow system using sharply focussed illumination. Journal of Histochemistry and Cytochemistry 25, 845-856.

STEEN, H. B. (1990). Light scattering measurement in an arc lampbased flow cytometer. Cytometry 11, 223-230.

Stoicheva, N. G., Davey, C. L, Markx, G. H. \& Kell, D. B. (1989). Dielectric spectroscopy: a rapid method for the determination of solvent biocompatibility during biotransformations. Biocatalysis $\mathbf{2}$, 245-255.

Stouthamer, A. H. \& Bettenhaussen, C. W. (1976). Energetic aspects of anaerobic growth of Aerobacter aerogenes in complex medium. Archives of Microbiology 111, 21-23.

Symons, M. R., Korenstein, R., Harris, C. M. \& Kell, D. B. (1986). Dielectric spectroscopy of energy coupling membranes: chloroplast thylakoids. Bioelectrochemistry and Bioenergetics 16, 45-54.

Takashima, S. (1989). Electrical Properties of Biopolymers and Membranes. Bristol: Adam Hilger.

TEMPEST, D. W. (1970). The continuous cultivation of microorganisms. 1. Theory of the chemostat. Methods in Microbiology 2, 260-276.

TrIVEDI, N. B. \& JACOBSON, G. (1986). Recent advances in baker's yeast. Progress in Industrial Microbiology 23, 45-71.

VAN UdEn, N. (1989). Alcohol Toxicity in Yeasts and Bacteria. Boca Raton, Florida: CRC Press.

WATSON, T. G. (1969). Steady state operation of a continuous culture at maximum growth rate by control of carbon dioxide production. Journal of General Microbiology 59, 83-89.

Watson, T. G. (1972). The present status and future prospects of the turbidostat. Journal of Applied Chemistry 22, 229-243.

WYATT, P. j. (1968). Differential light scattering: a physical method for identifying living bacterial cells. Applied Optics 7, 1879-1896.

ZIMMERMANN, U. (1982). Electric field-mediated cell fusion and related electrical phenomena. Biochimica et Biophysica Acta 694, 227-277. 